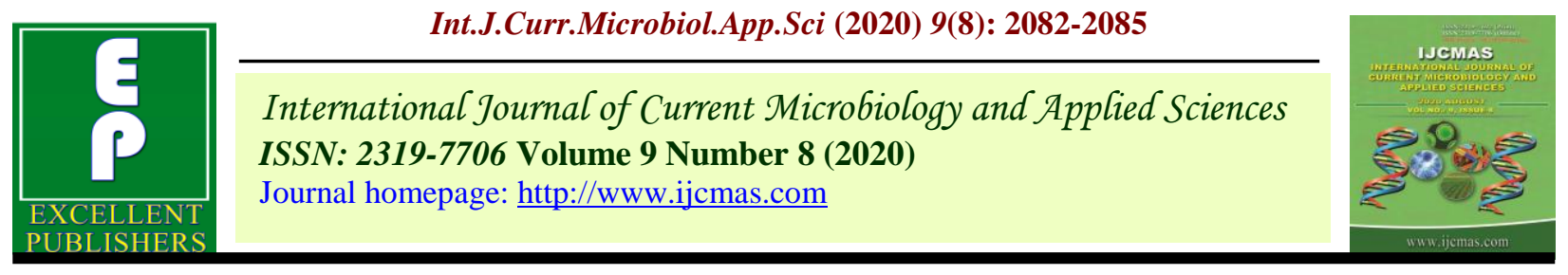

Original Research Article

https://doi.org/10.20546/ijcmas.2020.908.236

\title{
Performance Evaluation of Wheat under Surface and Sub-Surface Drip Irrigation Using Saline and Good Quality Water
}

\author{
Ashok Choudhary*, Pankaj Kumar Kaswan, Ramesh Kumar, \\ Sheilendra Kumar and A.K. Singh
}

Precision Farming Development Centre, Agricultural Research Station (ARS), Swami Keshwanand Rajasthan Agricultural University (SKRAU), Bikaner, Rajasthan, India

*Corresponding author

\begin{tabular}{|l||}
\hline Ke y w o r d s \\
Irrigation water \\
quality, Saline \\
water, Wheat, \\
Surface and sub \\
surface drip
\end{tabular}

\section{A B S T R A C T}

An experiment was conducted to study the performance of wheat under surface and sub-surface drip irrigation using saline \& good quality waters at the Precision Farming Development Centre, ARS, Swami Keshwanand Rajasthan Agricultural University, Bikaner during 2016-2019 on loamy sand soil. The experiment comprised of two levels of irrigation water salinity viz., 0.25 (BAW) and $2.76 \mathrm{dS} / \mathrm{m}$, two drip system (surface and subsurface) under Randomized Block Design (RBD) with six replications. Application of best available water gave significantly higher yield (37.54 $\mathrm{q} / \mathrm{ha}$ ) with the tune of 7.71 per cent over saline water and sub surface irrigation yielded (39.21 q/ha) significantly higher over surface drip irrigation method. Further result shows that highest fodder yield obtained by best available water (54.77 $\mathrm{q} / \mathrm{ha})$ and sub surface drip irrigation (52.33 $\mathrm{q} / \mathrm{ha}$ ) system over saline water and surface drip irrigation system.

\section{Introduction}

Water scarcity is becoming one of the major limiting factors for sustainable agriculture in the semi-arid regions of the world. Not only fresh water, but also wheat production is not enough. Consequently, saline water for deficit irrigation has to be taken into account. Increased agricultural production has become an urgent requirement of the expanding world population. Yet, there has been a continued decrease in available fresh water that can be used by agricultural production. At the same time, the quality of irrigation water has also deteriorated. According to soil salinity, wheat is classified to be salt tolerant (Katerji et al., 2000). Khosla and Gupta (1997) found that wheat height and yield increased with irrigation amount under drained conditions, but they were decreased under poor drained conditions. Datta et al., (1998) reported that yields decreases with the rise in irrigation quantity under saline conditions. Saline water has been used successfully for agricultural 
irrigation. Crop yield is the most important consideration in the utilization of saline water (Malash et al., 2005). Subsurface drip irrigation systems may increase water use efficiency (WUE) due to reduced soil and plant surface evaporation and because only the root zone or the partial root zone is irrigated as opposed to sprinkler irrigation where the entire field area is wetted. Crop growth parameters and yield under combined deficit and saline water irrigation were different to those under separate deficit or saline irrigation. Ayers, et al., (1993) reported that the combination of drought and salinity reduced the water availability for crops at a more significant rate than the separate effect of either salinity or drought alone. According to Hachicha et al., (2006), salt accumulates on the soil surface before migrate and reach the root zone when drip irrigation is used. Subsurface drip irrigation has been developed to improve salinity management and water use efficiency.

Surface drip irrigation decreases the accumulation of salts at the root zone level of plants, producing an improved yield and fruit quality. Ground water quality of Bikaner district is not good and has the problem of salinity. Overhead sprinklers are used for irrigation resulting in low water use efficiency with depletion of ground water reservoir in this arid region. Drip irrigation is the right option in this situation which not only enhances WUE but poor quality water can also be used safely with minimum hazard on soil and plant. Use of drip irrigation system for saline water is the most suitable technology for judicious leaching fraction. Thus, drip system not only saves irrigation water but also does not permit salt accumulation in vicinity of root zone. Drip irrigation system has been found to be quite effective under limited water availability not only in achieving higher productivity but also economizing other in puts such as fertilizers, pesticides, labor etc. Drip irrigation system is a conventional and effective means of supplying water directly to soil and nearer to the plant without much loss of water resulting in higher water productivity (Banyopadhyay et al., 2005).

\section{Materials and Methods}

The field experiment was conducted at Precision Farming Development Centre, Agricultural Research station, Swami Keshwanand Rajasthan Agricultural University, Bikaner, Rajasthan, India $\left(28^{\circ}\right.$ $01^{\prime} \mathrm{N}$ latitude and $73^{\circ} 22^{\prime} \mathrm{E}$ longitude at an altitude of 234.70 meters above mean sea level) during kharif season of 2016, 2017 and 2018. The soil of experimental field was loamy-sand, alkaline in reaction $(\mathrm{pH}$ 8.2) having $120 \mathrm{~kg} / \mathrm{ha}$ available $\mathrm{N}$ (Alkaline permanganate method, low level of available phosphorus $(15.1 \mathrm{~kg} / \mathrm{ha}$, Olsen's method and medium in available potassium $(173.7 \mathrm{~kg} / \mathrm{ha}$, Flame photometric method in $0-15 \mathrm{~cm}$ soil depth at the start of the experiment.

The experiment was planned to study the performance evaluation of wheat under surface and sub-surface drip irrigation system using saline water. The treatments comprised of two levels of irrigation water quality (BAW and saline water) and two drip systems (surface and sub-surface) under Randomized Block Design (RBD) with six replications. Wheat was grown as per standard agronomic practices. Irrigation was applied through inline drip with discharge rate of 4 liters per hour per emitter. Irrigations were scheduled on alternate day basis and fertilizers were applied through drip. The yield attributes and yields were recorded and data were statistically analyzed for estimation of analysis of variance as per method suggested by (Panse and Sukhatme, 1985). The critical differences between the observed values under different treatment combinations were 
also estimated to understand the significant effects of different saline waters and irrigation system.

\section{Results and Discussion}

\section{Irrigation system}

Drip irrigation systems showed a significant variation in yield attributes. The grain yield and fodder yield exhibited the superiority with use of sub surface irrigation system over surface drip irrigation system, though, the differences were significant. Sub surface drip irrigation system produced significantly higher seed and fodder yield with the tune of 18.17 and 19.20 per cent over surface drip irrigation, which might be due to less salt accumulation in rhizosphere under sub surface drip irrigation than surface drip irrigation system.

\section{Irrigation water quality}

Three years pooled data revealed that quality of irrigation water had profound effect on yield and fodder yield (Table 1). The significantly higher value of their yield and fodder yield were obtained with use of BAW over saline water with the tune of 7.71 per cent and 8.14 per cent, respectively over saline water. The reduction in yield parameters might be due to harmful effect of salts in physiological processes. Photosynthesis, nutrient absorption and uptake decrease and photorespiration increases which results in lower photosynthates assimilation and ultimately leads to poor yields. Pasternak (1987) informed unlike flood irrigation, drip irrigation leaches salt away from rhizosphere and maintains a low soil moisture tension. Kang (2004) stated that the low rate and high frequent irrigation applications of drip irrigation system, over a long period of time, can maintain high soil matric potential in root zone, compensating for the decrease of osmotic potential introduced by the saline water irrigation, and constant high water potential can be maintained for the crop growth (Table 2).

Table.1 Response of irrigation mode and quality of water, on yield attributes of Wheat

\begin{tabular}{|c|c|c|c|c|c|c|c|c|}
\hline \multirow[t]{2}{*}{ Treatments } & \multicolumn{4}{|c|}{ Yield (q/ha) } & \multicolumn{4}{|c|}{ Fodder Yield (q/ha) } \\
\hline & $\begin{array}{c}\text { 2016- } \\
17\end{array}$ & $\begin{array}{c}2017- \\
18\end{array}$ & $\begin{array}{c}\text { 2018- } \\
19\end{array}$ & Pooled & $\begin{array}{c}\text { 2016- } \\
17\end{array}$ & $\begin{array}{c}2017- \\
18\end{array}$ & $\begin{array}{c}2018- \\
19\end{array}$ & Pooled \\
\hline Surface drip & 32.86 & 33.49 & 35.79 & 33.18 & 43.67 & 48.24 & 48.72 & 45.95 \\
\hline Sub surface Drip & 38.66 & 39.76 & 42.46 & 39.21 & 51.90 & 57.64 & 58.19 & 54.77 \\
\hline S.Em. \pm & 0.69 & 0.75 & 0.75 & 0.40 & 0.87 & 1.12 & 1.18 & 0.56 \\
\hline C.D. $(5 \%)$ & 2.18 & 2.36 & 2.36 & 1.16 & 2.74 & 3.54 & 3.72 & 1.62 \\
\hline BAW & 37.06 & 38.03 & 40.62 & 37.54 & 49.63 & 55.04 & 55.57 & 52.33 \\
\hline Saline water & 34.47 & 35.22 & 37.64 & 34.85 & 45.94 & 50.84 & 51.33 & 48.39 \\
\hline S.Em. \pm & 0.56 & 0.60 & 0.60 & 0.34 & 0.70 & 0.91 & 0.97 & 0.47 \\
\hline C.D. $(5 \%)$ & 2.04 & 2.20 & 2.20 & 1.01 & 2.56 & 3.30 & 3.52 & 1.41 \\
\hline
\end{tabular}


Table.2 Salinity $\left(\mathrm{EC}_{\mathrm{e}}\right)$ build-up in the soil profile after harvesting of wheat

\begin{tabular}{|c|c|c|c|}
\hline \multirow{3}{*}{$\begin{array}{l}\text { Distance from emitter } \\
(\mathbf{c m})\end{array}$} & \multirow{3}{*}{$\begin{array}{l}\text { Soil depth } \\
\quad(\mathrm{cm})\end{array}$} & \multicolumn{2}{|c|}{$\mathrm{EC}_{\mathrm{iw}}(\mathrm{dS} / \mathrm{m})$} \\
\hline & & \multicolumn{2}{|c|}{ Surface Drip } \\
\hline & & 0.25 & 4.0 \\
\hline $\mathbf{0}$ & $0-15$ & 0.31 & 0.67 \\
\hline & $15-30$ & 0.35 & 0.73 \\
\hline & $30-45$ & 0.39 & 0.89 \\
\hline 15 & $0-15$ & 0.36 & 0.76 \\
\hline & $15-30$ & 0.39 & 0.81 \\
\hline & $30-45$ & 0.43 & 0.98 \\
\hline 30 & $0-15$ & 0.39 & 0.89 \\
\hline & $15-30$ & 0.43 & 1.07 \\
\hline & $30-45$ & 0.51 & 1.31 \\
\hline
\end{tabular}

It is concluded that in the tube well irrigated area where water salinity is around $4 \mathrm{dS} / \mathrm{m}$, wheat could be cultivated successfully using drip system with about $10 \%$ reduction in yield as compare to best available water. Subsurface drip system for wheat crop using good quality of water results in increased yield of approximately $5.0 \mathrm{q} / \mathrm{ha}$ over surface drip system.

\section{References}

Ayars J E, Hutmacher R B, Schoneman R A. , S. S. Vail, T. Pflaum, 1993. Long term use of saline water for irrigation. Irrigation Science, 14: 27-34.

Banyopadhyay PK, Mallick S and Rana SK (2005) Water balance and crop coefficient of summer grown peanut (Arachis hypogaea L.) in humid tropical region of India. Irrig. Sci. 23: 161-169.

Datta, K.K., Sharma, V.P. and Sharma, D.P., 1998. Estimation of a production functions for wheat under saline conditions. Agricultural Water Management 36:85-94.

Hachicha, M., H. Nahdi, S. Rejeb, 2006. Effect de l'irrigation au goutte à goutte outerraine avec l'eau salée sur une culture de piment. Ann. INRAT, 79, 85-103.

Kang Y. H. (1993) Microirrigation for the development of sustainable agriculture. Trans. CASE 14: 251-255.

Katerji N, M. Mastrorilli, J. W. van Hoorn, 2009. Durum wheat and barley productivity in saline-drought environments. European Journal of Agronomy, 31: 1-9.

Khosla, B. K. and R.K. Gupta, 1997. Response of wheat to saline irrigation and drainage. Agricultural Water Management, 32: 285291.

Malash N, T. J. Flowers and R. Ragab, 2005. Effect of irrigation systems and water management practices using saline and nonsaline water on tomato production. Agricultural Water Management, 78: 25-38.

Panse VG and Sukhatme PV (1985) Statistical Methods for Agricultural Workers 2nd Ed. Indian Council of Agricultural Research Publication, New Delhi.

Pasternak D. (1987) Salt tolerance and crop production-a comprehensive approach. Annu Rev Phytopathol 25: 271-291.

\section{How to cite this article:}

Ashok Choudhary, Pankaj Kumar Kaswan, Ramesh Kumar, Sheilendra Kumar and A.K. Singh. 2020. Performance Evaluation of Wheat under Surface and Sub-Surface Drip Irrigation Using Saline \& Good Quality Water. Int.J.Curr.Microbiol.App.Sci. 9(08): 2082-2085. doi: https://doi.org/10.20546/ijcmas.2020.908.236 